AperTO - Archivio Istituzionale Open Access dell'Università di Torino

\title{
Improvement of HRV Quantification Using cRNA-Based Standards for Real Time RT-PCR
}

\section{This is the author's manuscript}

Original Citation:

Availability:

This version is available http://hdl.handle.net/2318/83605

since

Published version:

DOI:10.1007/s12033-010-9343-9

Terms of use:

Open Access

Anyone can freely access the full text of works made available as "Open Access". Works made available under a Creative Commons license can be used according to the terms and conditions of said license. Use of all other works requires consent of the right holder (author or publisher) if not exempted from copyright protection by the applicable law. 


\section{(3) \\ UNIVERSITÀ DEGLI STUDI DI TORINO}

The final publication is available at Springer via

http://link.springer.com/article/10.1007\%2Fs12033-010-9343-9 


\section{Improvement of HRV quantification using cRNA-based standards for Real Time RT-PCR.}

Maria Elena Terlizzi, Massimiliano Bergallo, Sara Astegiano, Francesca Sidoti, Stefano Gambarino, ${ }^{1}$ Paolo Solidoro, Cristina Costa, Rossana Cavallo.

Virology Unit and ${ }^{1}$ Division of Pneumology, University Hospital San Giovanni Battista di Torino, Turin, Italy.

mariaelena.terlizzi@unito.it; massimiliano.bergallo@unito.it; sara.astegiano@unito.it; francesca.sidoti@unito.it; stefano.gambarino@unito.it; psolidoro@molinette.piemonte.it; cristina.costa@unito.it; rossana.cavallo@unito.it

\section{Corresponding author}

Cristina Costa, MD

Virology Unit, University Hospital San Giovanni Battista di Torino

Via Santena 9 - 10126 Torino - ITALY

Telephone number $+39(11) 6705630$

Fax number $+39(11) 6705648$

E-mail address: cristina.costa@unito.it 


\section{Abstract}

Real Time RT-PCR developed in recent years represents an useful tool in the diagnosis of RNA viruses. In order to accurately quantify and normalize a RNA target, efficiency of reverse-transcription must be considered. In this study a cRNA-standard based quantitative Real Time RT-PCR have been developed for HRV quantification on bronchoalveolar lavage (BAL) specimens. Results has been compared to a quantitative plasmid standard-based Real Time RT-PCR previously developed by us.

Large amount of pHRV was linearized and purified. Blunt ends were generated and cRNA production was carried out. Dilutions of cRNA were generated and dynamic range, intraand inter-test variability, sensitivity and limit of detection were evaluated. Sixty-seven BAL, previously resulted positive to our plasmid standard-based method, were evaluated using cRNA-standard quantification.

cRNA curve showed a broad dynamic range with a good intra- and inter-test variability, with an average of 3.23 threshold cycles more in comparison to plasmid standard-based curve. In terms of specimen quantification, a difference of $1.07 \log$ was found, showing a significant underrate using plasmid standard-based quantification.

The method for cRNA-standard construction seems more suitable for quantification of RNA viruses, in order to normalize the quantification in reverse-transcription.

Keywords: Human Rhinovirus; cRNA; Real Time RT-PCR; BAL. 


\section{Introduction}

In recent years, a variety of techniques for measurement of the absolute concentration of specific RNA sequences have been developed, such as nucleic acid based-sequence amplification (NASBA), transcription-mediated amplification (TSA) and reverse transcription-PCR (RT-PCR) or Real Time RT-PCR. Among these methods, Real Time RTPCR is the most used and many platforms are available in the routine laboratories $(1,2,3)$. In the assessment of a Real Time RT-PCR assay several factors have to be evaluated, such as efficiency of nucleic acids extraction, reverse-transcription and amplification, with this latter consisting of sensitivity, specificity (elsewhere defined as inclusivity and exclusivity), linearity, intra- and inter-test variability (or repeatability and reproducibility) (4). In literature, many Real Time RT-PCR assays are assessed using a plasmid-based standard curve, through their introduction in amplification step, thus generating an intrinsic error because of uncontrolled extraction and reverse transcription steps. At this regard, RNA could be most accurately and appropriately measured through the use of reliable RNA preparations, calibrated to known concentrations as referred as cRNA standards $(5, \underline{6})$. The aim of this study was to develop an in vitro-transcribed cRNA-based standard method to quantify Human Rhinoviruses (HRV) by Real Time RT-PCR and to compare it with a plasmid-based standard method on bronchoalveolar lavage (BAL) specimens in terms of quantification capability, efficiency, sensitivity, linearity, detection limit, repeatability and reproducibility. 


\section{Materials and Methods}

DNA plasmid standards were constructed as previously described (7). As regards cRNA standards, a large amount of HRV plasmid were obtained using PureLink ${ }^{\mathrm{TM}}$ HiPure Plasmid Midiprep Kit (Invitrogen, Carlsbad, USA) following manufactures' instructions. Twelve micrograms of HRV-DNA plasmid was first linearized using SacI restriction enzyme (New England Biolabs, Inc., USA) at $37^{\circ} \mathrm{C}$ for $2 \mathrm{~h}$ followed by inactivation at $65^{\circ} \mathrm{C}$ for 20 minutes. In order to avoid aspecific cutting inside of target sequence, digestion profile on Restriction mapper version 3 (available on line) was performed. Digested DNA was purified using Blood \& Cell Culture DNA Mini Kit (Qiagen, Hiden, Germany) following manufactures' instructions. DNA Polymerase I, Large (Klenow) Fragment (Invitrogen, Carlsbad, USA) was used to blunt DNA ends at $22^{\circ} \mathrm{C}$ for 15 minutes. cRNA production was carried out using T7-RiboMAX Large Scale RNA Production Systems (Promega, USA) at $37^{\circ} \mathrm{C}$ for $4 \mathrm{~h}$. One-tenth of cRNA product was treated with RQ1 RNase-Free DNase (Promega, USA) at $37^{\circ} \mathrm{C}$ for 15 minutes followed by incubation with EDTA for 15 minutes at $65^{\circ} \mathrm{C}$. HRV-cRNA was purified using RNAgent kit (Promega, USA) following manufactures' instructions. HRV-cRNA was quantified using Quant-iT DNA BR Assay on Qubit $^{\mathrm{TM}}$ fluorometer (Invitrogen, Carlsbad, USA). Ten-fold dilutions of cRNA were generated in order to amplify from $10^{10}$ to $10^{\circ}$ copies per reaction. cRNA dilutions were extracted using NucliSens easyMAG platform (bioMerièux, Marcy l'Etoile, France) as well as biological samples. Viral ccDNA was generated, first by incubation of random primers (6oong/ $\mu \mathrm{l})$ and dNTPs (10mM) (Invitrogen) with $10 \mu \mathrm{l}$ of cRNA for 5 minutes at $70^{\circ} \mathrm{C}$. Subsequently, a mix containing buffer $5 \times$ [250mM Tris- $\mathrm{HCl}\left(\mathrm{pH} 8.3\right.$ at $\left.25^{\circ} \mathrm{C}\right), 375 \mathrm{mM} \mathrm{KCl}$ and 5OmM DTT], $\mathrm{MgCl}_{2}(25 \mathrm{mM})$, ImpromII RT ( $\left.1 \mathrm{U} / \mu \mathrm{l}\right)$ and Recombinant RNasin $\AA$

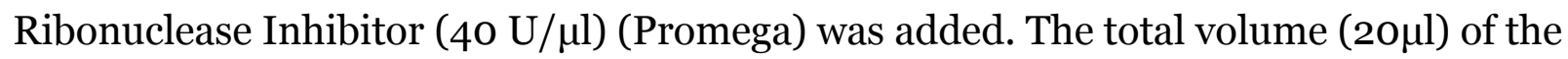
reaction mixture was incubated for 5 minutes at $25^{\circ} \mathrm{C}, 60$ minutes at $42{ }^{\circ} \mathrm{C}, 15$ minutes at $70{ }^{\circ} \mathrm{C}$ using 9800 Fast Thermal Cycler (Applied Biosystems, Monza, Italy). The RT-Real 
Time PCR was optimized using the final primers and probe concentrations of $250 \mathrm{OM}$ and $125 \mathrm{nM}$, respectively. Two microliters of ccDNA were added to $18 \mu \mathrm{l}$ of the reaction mix, giving a final reaction volume of $20 \mu \mathrm{l}$ using the thermal profile previously described (7). Different features were analyzed including the quantification capability, efficiency, sensitivity, linearity, detection limit, repeatability and reproducibility as described elsewhere (7). A total of 67 BAL specimens were extracted using an automated extraction of combined DNA/RNA using NucliSens easyMAG platform (bioMerièux). RNA was extracted from 250:250 $\mu \mathrm{l}$ volume of clinical specimens: $\mathrm{N}$-acetilcysteine, according to manufacturer's instructions, and eluted to a final volume of $110 \mu \mathrm{l}$. A total of $10 \mu \mathrm{l}$ of extracted RNA was subjected to reverse transcription following cRNA standards procedure. 


\section{Results.}

The main features of cRNA-based Real Time RT-PCR are reported on table 1. The assay was optimized by repeated testing of serial logarithmic dilutions of standard curve. The actual sensitivity of assay was determined by the lowest standard dilution consistently detectable in replicate reactions at a frequency of $100 \%$ and it was found to be 100 copy/reaction and was linear (quantifiable) up to $10^{2}$ copies. Linearity range was from $10^{10}$ to $10^{2}$ copies/reaction with a $\mathrm{R}^{2}$ index higher than 0.990 . The efficiency of our cRNA-based Real Time RT-PCR assay was 1.91. The assay showed a good repeatability (CV \% of 1.91 for $10^{2}, 1.93$ for $10^{3}, 1.10$ for $10^{4}, 0.42$ for $10^{5}$ ) and reproducibility (CV \% of 2.01 for $10^{2}, 2.12$ for $10^{3}, 1.92$ for $10^{4}, 1.72$ for $10^{5}$ ). In table 1 differences among two Real Time RT-PCR assays are highlighted. As regards quantification capability, comparison among standard curves (plasmid-based versus cRNA-based) is reported in table 2. In particular, a mean difference of 3.23 Ct was highlighted, consisting in a right shift of cRNA-based standard curve compared to plasmid-based one, as reflected by the intercept values (38.42 for plasmidversus 43.07 for cRNA-based standard curve). Sixty-seven bronchoalveolar lavages (BAL), previously resulted positive to HRV using plasmid-based standard curve Real Time RTPCR, were re-quantified using the developed cRNA-based standard curve. In terms of BAL quantification, a mean difference of 1.07 logarithm was observed. In terms of quantification capability, the use of plasmid-based standard curve lead to an overall underrate caused by the displacement. 


\section{Discussion}

The development of a "in-house" Real Time RT-PCR assay, available for diagnostic routine, requires an analogous process applied to marked and approved commercial kit for diagnostic use $(4,8)$. This is realized by the standardization and optimization of the amplification protocol; however, also RNA extraction and reverse transcription protocols should be considered in the method assessment. At this regards, in this study an external in vitro synthesized cRNA standard is generated in order to obtain a calibration standard curve, thereby offering some advantages as control and standardization of RNA extraction and reverse transcription. The sensitivity of our assay was found to be of 100 copy/reaction with a linearity range from $10^{10}$ to $10^{2}$ copies/reaction, characterized by a good efficiency, repeatability and reproducibility, comparable to those found in plasmid-based standard curve (7). Sensitivity parameter resulted one-logarithm lower in cRNA-based Real Time RT-PCR in comparison to plasmid-based Real Time RT-PCR, due to the displacement toward the right of cRNA standard curve that is also responsible for the difference in term of quantification. The use of plasmid-based standard curve lead to an overall underrate caused by the displacement of cRNA-based standards, as evidenced when considering intercepta values of standard curve equations. The displacement could be explained by the efficiency of nucleic acid extraction and reverse-transcription, the values of which are below to $100 \%$, leading to a variable loss of initial RNA target amount. Considering that evaluation of the nucleic acid extraction and reverse-transcription efficiencies has a great impact on final quantification, this has to be taken into account in the assessment of a Real Time RT-PCR assay. While the efficiency of nucleic acid extraction is well documented and declared in manufacturer's protocols, less informations are available about the efficiency of the reverse-transcription kits. Generally, the reverse transcription efficiency depends on many factors, including those RT enzyme-dependent (as presence of co-factors, salt concentrations and temperature) and those target-dependent (as initial RNA amount and 
RNA background) (9). Overall, the unique condicio sine qua non for cRNA standard synthesis is represented by the presence of a RNA polymerase promoter-binding site into the vector containing the amplicon of interest (many commercial products, comprising those used in our protocol, are characterized by the presence of T7-RNA polymerase promoter) and the choice of the in vitro transcription kit depends on it (5). On the other hand, the cRNA based method may present some limitations. As though RNA standards can be used, their stability could be a source of variability in the final analyses, thus requiring a thorough evaluation of nonconformities. In addition, using RNA standards would involve the construction of cDNA plasmids that have to be in vitro transcribed into the RNA standards and accurately quantitated, which could be a time-consuming process. Nonetheless, the use of absolutely quantitated RNA standards will help generate absolute copy number data.

In conclusion, herein we evaluated two different approaches to HRV quantification by Real Time RT-PCR, using cRNA- and plasmid-based standard curves. Considering our results, the cRNA-based approach could be usefully applied for a more appropriate measurement of RNA viruses in biological samples. 


\section{References}

1. Romano, J.W., van Gemen, B., Kievits, T. (1996) NASBA: a novel, isothermal detection technology for qualitative and quantitative HIV-1 RNA measurements. Clin. Lab. Med. $16,89-103$.

2. Gill, P. and Ghaemi, A. (2008) Nucleic acid isothermal amplification technologies: a review. Nucleosides Nucleotides Nucleic Acids. 27, 224-243.

3. Espy, M.J., Uhl, J.R., Sloan, L.M., Buckwalter, S.P., Jones, M.F., Vetter, E.A., Yao, J.D., Wengenack, N.L., Rosenblatt, J.E., Cockerill, F.R., Smith, T.F. (2006) Real-time PCR in clinical microbiology: applications for routine laboratory testing. Clin. Microbiol. Rev. $19,165-256$.

4. Niesters, H.G.M. (2004) Molecular and diagnostic clinical virology in real time. Clin. Microbiol. Infect. 10, 5-11.

5. Fronhoffs, S., Totzke, G., Stier, S., Wernert, N., Rothe, M., Bru“ning, T., Koch, B., Sachinidis, A., Vetter, H., Ko, Y. (2002) A method for the rapid construction of cRNA standard curves in quantitative real-time reverse transcription polymerase chain reaction. Molecular and Cellular Probes 16, 99-110.

6. Monne, I., Ormelli, S., Salviato, A., De Battisti, C., Bettini, F., Salomoni, A., Drago, A., Zecchin, B., Capua, I., Cattoli, G. (2008) Development and validation of a one-step realtime PCR assay for simultaneous detection of subtype $\mathrm{H}_{5}, \mathrm{H}_{7}$, and $\mathrm{H}_{9}$ avian influenza viruses. J. Clin. Microbiol., 46, 1769-73

7. Gambarino, S., Costa, C., Elia, M., Sidoti, F., Mantovani, S., Gruosso, V., Bergallo, M., Cavallo, R. (2009) Development of a RT real-time PCR for the detection and quantification of human rhinoviruses. Mol. Biotech. 42, 350-357. 
8. Raymaekers, M., Smets, R., Maes, B., Cartuyvels, R. (2009) Checklist for Optimization and Validation of Real-Time PCR Assays. J. Clin. Lab. Anal. 23, 145-151

9. Levesque-Sergerie, J.P., Duquette, M., Thibault, C., Delbecchi, L., Bissonnette, N. (2007) Detection limits of several commercial reverse transcriptase enzymes: impact on the low- and high-abundance transcript levels assessed by quantitative RT-PCR. BMC Mol. Biol. 22, 8-93. 
Table 1. Main technical features of cRNA-based standard Real Time RT-PCR in comparison to plasmid-based standard Real Time RT-PCR.

\begin{tabular}{|c|c|c|c|}
\hline & & $\begin{array}{l}\text { Plasmid- } \\
\text { based } \\
\text { standard } \\
\text { curve }\end{array}$ & $\begin{array}{l}\text { cRNA- } \\
\text { based } \\
\text { standard } \\
\text { curve }\end{array}$ \\
\hline \multicolumn{2}{|l|}{$\begin{array}{l}\text { Linearity range } \\
\text { (copies/reaction) }\end{array}$} & $10^{7}-10^{1}$ & $10^{10}-10^{2}$ \\
\hline \multicolumn{2}{|l|}{ Sensitivity } & 10 & 100 \\
\hline \multicolumn{2}{|l|}{ Limit of detection } & 10 & 100 \\
\hline \multicolumn{2}{|l|}{ Efficiency } & 2.08 & 1.91 \\
\hline \multirow{4}{*}{ Ripetibility (CV\%) } & 1 & 0.47 & 1.91 \\
\hline & 1 & 0.67 & 1.93 \\
\hline & 1 & 0.63 & 1.10 \\
\hline & $\begin{array}{l}1 \\
0 \\
5\end{array}$ & 0.09 & 0.42 \\
\hline \multirow{4}{*}{$\begin{array}{l}\text { Reproducibility } \\
\text { (CV\%) }\end{array}$} & 1 & 0.79 & 2.01 \\
\hline & 1 & 1.70 & 2.12 \\
\hline & 1 & 1.34 & 1.92 \\
\hline & $\begin{array}{l}1 \\
\text { o } \\
5\end{array}$ & 0.89 & 1.72 \\
\hline
\end{tabular}


Table 2. Comparison of standard curves (plasmid-based versus cRNA-based) for HRV quantification by Real Time RT-PCR.

\begin{tabular}{|c|c|c|c|}
\hline & $\begin{array}{c}\text { *Plasmid-based } \\
\text { standard curve }\end{array}$ & $\begin{array}{c}{ }^{* *} \mathrm{cRNA}- \\
\text { based } \\
\text { standard } \\
\text { curve }\end{array}$ & $\leftrightarrows(\mathrm{Ct})$ \\
\hline $10^{2}$ & 32,11 & 36,96 & 3,85 \\
\hline $10^{3}$ & 28,95 & 32,74 & 3,79 \\
\hline $10^{4}$ & 25,79 & 28,75 & 2,96 \\
\hline $10^{5}$ & 22,64 & 25,55 & 2,91 \\
\hline${ }^{*} \mathrm{y}=-3.16 \mathrm{x}+38.42\left(\mathrm{R}^{2}=0.997\right) ; * * \mathrm{y}=-3.56 \mathrm{x}+43.07\left(\mathrm{R}^{2}=0.998\right)$ \\
\hline
\end{tabular}

